Presidint P. J. Parrott: The next paper will be presented by Dr. C. Gordon Hewitt, entitled "Further Observations on the Breeding Habits of the House-fly and its Control."

\title{
FURTHER OBSERVATIONS ON THE BREEDING HABITS AND CONTROL OF THE HOUSE-FLY, MUSCA DOMESTICA
}

\author{
By C. Gondon HewitT. D. Sc., F. R. S. C. Dominion Entomologisl, Ouawa
}

The following account of certain investigations carried on during the past summer (1913) is of a preliminary character. It was considered desirable to communicate to the Association an interim report of this nature, primarily with a view to drawing the attention of other workers to the need of experimental work along similar lines. In so important a public problem as the control of house-flies, it is most desirable that the assistance of as many workers as possible should be enlisted, especially in a country containing so varied climatic, econnomic and other conditions.

Probably no entomological subject is now more popularly discussed than house-fly control, and as one who has, during the past eight years, devoted more attention to this subject than to any other entomological problem, I am bound to confess that in the matter of control measures there is still much to learn and we are far from having solved the basic problem of control, namely, the prevention of breeding. I am not referring particularly to the question of the construction of flyproof receptacles for stable-refuse and other fly breeding substances, but to the use of insecticidal substances under conditions which prohibit the taking of other precautions and render desirable the adoption of additional remedial measures.

It is in regard to control measures under rural conditions that we are most deficient in knowledge. For many reasons the prevention of breeding under urban conditions is, I believe, more subject to control. Civic authorities can insist on stables being constructed on certain approved lines, on the segregation of stables, a most important policy, on stable-refuse and garbage being stored according to prescribed methods, on the periodic removal of these breeding substances and so forth. All of which tend to reduce the problem to simple terms, though I should be the last to deny the inherent difficulties. Under rural conditions, however, the problem is different and it should be hardly necessary to indicate the importance of house-fly control in the country. One aspect alone, namely the possibility of milk contamination, and our milk supplies will always originate in the country, is sufficiently serious to warrant the greater attention to fly control 
measures in rural districts. In such districts conditions are not so easily controlled by health and other authorities, though very efficient control could be established by means of regulations governing the supply of milk to cities and towns requiring the inspection of farms and dairies. Nevertheless, we are faced with the problem of housefly control under rural conditions and we must examine it.

The farmer, if he does not store his stable refuse in fly-proof receptacles, will probably require a cheap and efficient insecticide. In addition he will usually ask what effect will the application of an insecticide have on the fertilizing of the manure. These are the problems we are called upon to solve and it was with a view to obtaining further data on the comparative value of insecticides in the control of houseflies under rural conditions and the effect of such treatment on the fertilizing properties of the manure that the special investigation which I commenced during the past summer was undertaken.

A number of investigators have previously carried on experiments along these lines, among whom may be mentioned Howard at Washington, Forbes in Illinois, Herms in California, and Newstead in England, but I feel sure that they would be the first to agree with my contention that the problems, as I have briefly indicated them, are by no means solved and that much more experimental work is required. There are two distinct problems which the study of the comparative value of the insecticides involves, namely, their insecticidal value and their effect on the fertilizing properties of the manure. The latter problem must of necessity be studied largely if not entirely by the agricultural chemist, and as the study of the comparative manurial values has not been undertaken in the course of the past season's work but will be prosecuted, I hope, next year, I shall devote myself to a consideration of the first of these problems. I would impress upon other workers, however, the great desirability of studying the effect of the insecticides on the manure as the farmer requests information on that point.

In passing, I should not omit to refer to a frequent recommendation which is made to farmers as a means of prevention, namely, that the manure should not be stored in heaps but should be carted away immediately and spread. Where this can be done it is, of course, the simplest method of procedure; apart from that fact it has the additional advantage of being the best policy from the point of view of manurial values. Extensive experiments in Canada and the United States have demonstrated the advantage of spreading the manure over piling it. This, however, is by the way.

In order to judge the relative values of different insecticides it is necessary to decide upon a means of comparison. In making this 
choice there are two alternatives, namely, either to count the number of dead as compared with the living larvæ in the treated manure, or to count the flies emerging after treatment. In previous work of this nature the former standard has been employed as a rule. It has a serious defect, however, namely, that the portion of treated manure selected, presuming a fair amount has been treated, may not be typical of the whole; in fact my experiments have shown that it would be extremely difficult if not impossible to select an average sample. To this point I shall refer later. In my opinion the only satisfactory basis of comparison is the number of adult flies which emerge from the whole amount of the manure treated. The experiments about to be described were arranged with that object in view.

\section{Methods}

It was decided to use a cubic yard, that is twenty-seven cubic feet of manure, as the amount of manure to be treated and the number of flies emerging from a cubic yard of untreated manure would be used as the standard of comparison. As experience demonstrated the actual quantity of manure was a little less than twentyseven cubic feet owing to the sinking of the manure. In spite of the cubic yard being heaped up it settled to a depth at the sides of two feet six inches on the average, thus giving approximately twenty-two cubic feet of manure after settling.

To contain the manure wire enclosures (Plate 9) were constructed of strong one-inch galvanized poultry wire supported by wooden stakes and cross-pieces at the top which was open. The stakes were driven into the ground until three feet of wire remained above ground.

The horse manure, which was mixed with an average quantity of straw used in the stables, was carted straight from the stable and thrown into the wire enclosures and trodden down as it was thrown in to obtain a fairly compound and typical manure heap. The top of the pile was made higher than the enclosure to allow for the settling which took place in spite of the packing. The sandy soil was piled up around the base of each heap to provide accommodation for the pupation of the larvæ.

Six such piles of manure were used. In some cases they were left for two days to allow the flies to oviposit, in other cases, for example, where chloride of lime was used, they were treated immediately after the enclosures had been filled. After exposure for two to three days and treatment with the insecticides the heaps were covered with wooden covers as shown in plate 9 . These covers were made sufficiently large to leave a space of about six inches all around the wire enclosures when they were covered. Two holes were provided in the top for wire balloon fly traps to capture the flies as they emerged. 


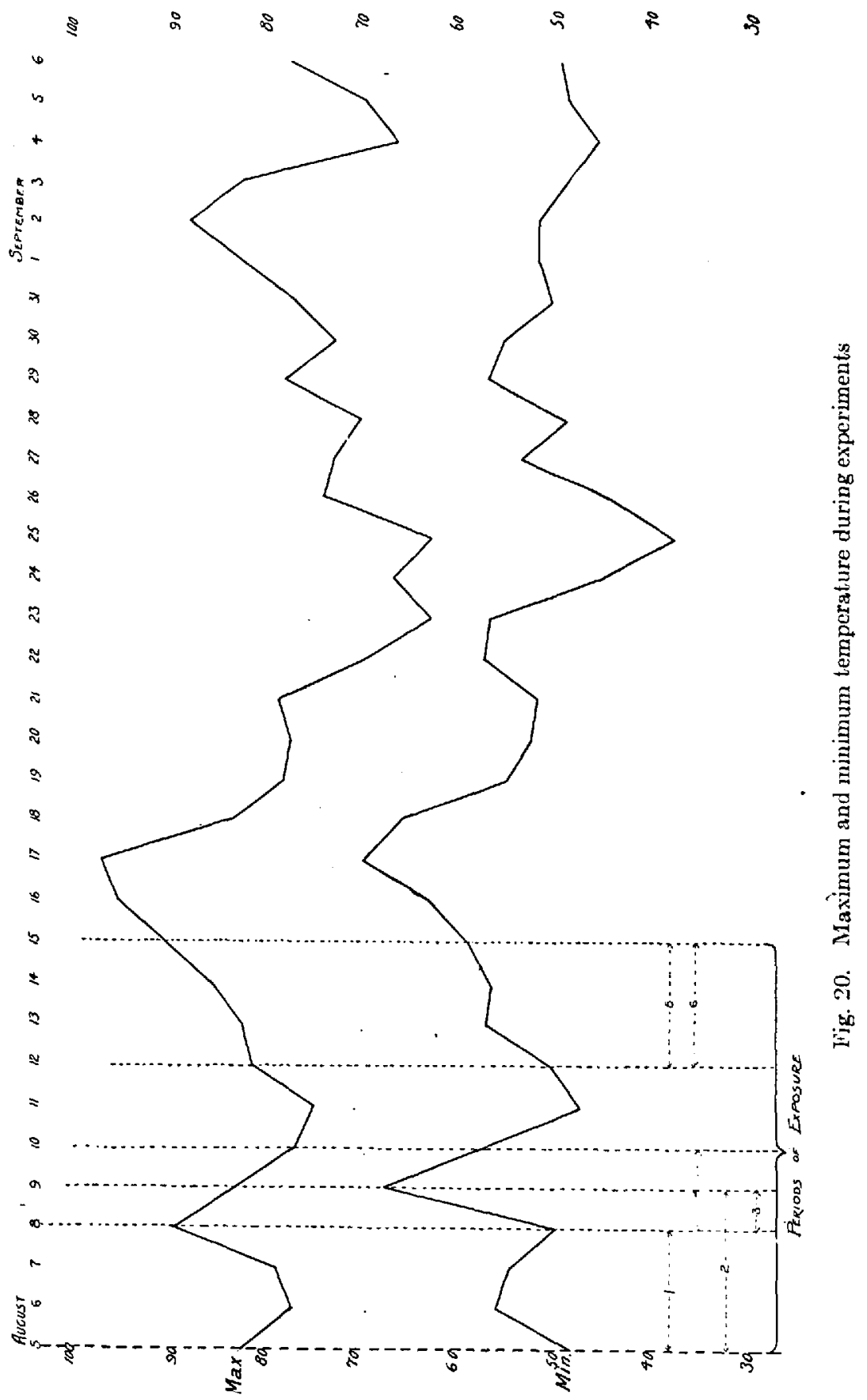


It was not long before experimental results were obtained but these were not of the nature which I had planned to secure. In spite of the fact that the lower edges of the wooden covers had been sunk in trenches and the soil piled round, it was found that some of the larvæ tunnelled beneath the cases and pupated in the soil piled outside the case with the result that flies began to emerge outside where provision had to be made for them. In this way a few hundred flies escaped from each of the first two or three experiments, but not sufficient, I think, to materially affect the general results. Accommodation was immediately provided for the reception of these wanderers by covering the piled up soil round the outside of the wooden case with cheese cloth, as shown on plate 9 and the exit at the front led into a wire balloon fly-trap. After this no further trouble was experienced, but the circumstance threw additional light on the pupating habits of the larvæ to which I shall refer later (see Pupation).

The emerging flies were caught in the wire traps and were counted once or twice daily as circumstances demanded. Heat was used as the means of killing them. I wish to acknowledge my indebtedness to my assistants Mr. Germain Beaulieu, and Mr. Sydney N. Lord who carried out the work of counting the individual flies.

\section{EXPERIMENTS}

Six series of experiments, Nos. 11 (1) to 11 (6) were carried out and the following is a summary of the series:

Exp. No. 11 (1). Untreated. Manure piled August 5th. Covered August 8th on which date second stage larvæ were found very numerous immediately beneath the surface.

Exp. No. 11 (2). Iron sulphate treatment. Manure piled August 5th. Pile sprayed with iron sulphate ( 2 pounds in 1 gallon of water) on August 8th, on which date many second stage and a few third stage ${ }^{1}$ larva were found in surface layer. Four gallons were applied to the top and sides of heap with a hand spray pump using a coarse nozzle. The vertical sides of the heap made it more difficult to thoroughly drench the manure on the sides. Pile covered August 9.

Exp. No. 11 (3). Chloride of lime; surface treatment. Manure piled August 8th. After piling, 3 pounds of chloride of lime were sprinkled over the top and sides of the heap, the sprinkling of the vertical sides was difficult and not entirely satisfactory. On August 9th living third stage larvæ were found within an inch of the surface

${ }^{1}$ As the manure in ench case lay in the stable for two or three days before being hauled out and piled in the wire enclosures a certain number of eggs were deposited before hauling, in spite of the stable being screened. But this fact would not vitiate the results of these experiments. 
immediately beneath the chloride of lime in spite of a thunder-storm and heavy rain which should have carried the chloride of lime in solution through the upper layers. Covered pile same day, August 9.

Exp. No. 11 (4). Zenoleum treatment. Manure piled August 8th. August 9th larvæ in third stage were found very numerous immediately below the surface of pile. Sprayed with zenoleum. (3. ounces to 1 gallon of water) same date, using 4 gallons of the solution. Larvæ immediately beneath the surface were killed and about 20 minutes after spraying larvæ were found emerging on to the top of the manure, no doubt to die. An hour after the heap had been sprayed torrential rains fell and as a result the dilution of the insecticide would probably be affected. Pile covered August 10th.

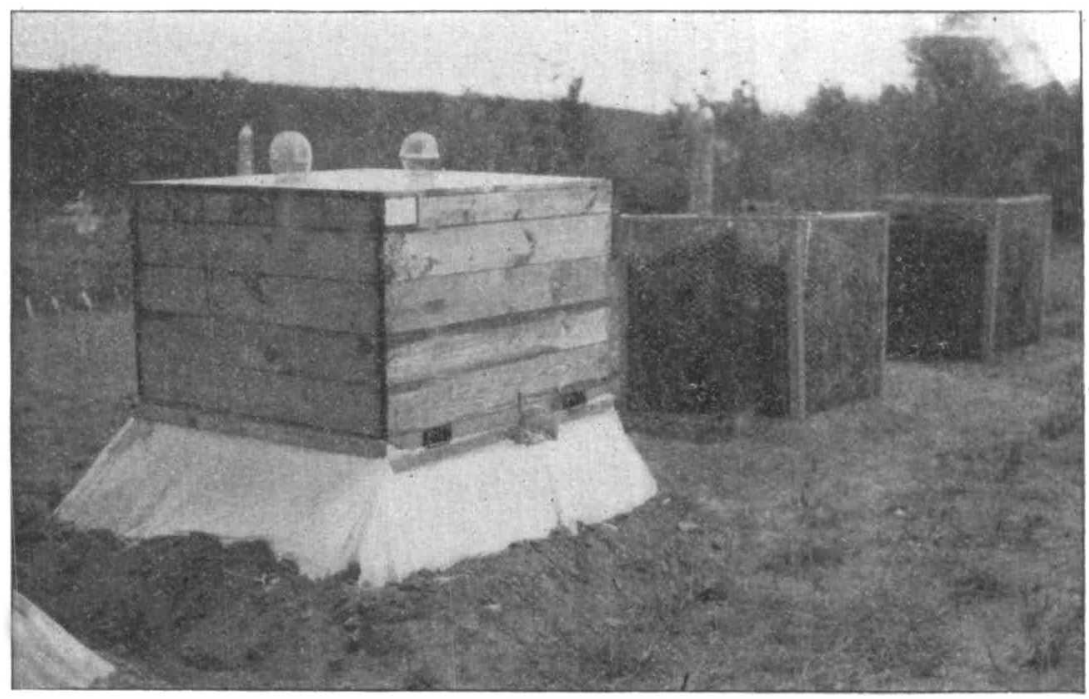

Fig. 21. Covered and uncovered manure piles used in the experiments

Exp. No. 11 (j). Chloride of lime; mixed treatment. Manure piled August 12th. As it. was being thrown in the enclosure chloride of lime was lightly scattered over the top and on the sides, $4 \frac{3}{4}$ pounds of the chemical being used on the cubic yard of manure. This manure had lain in the stable from 1 to 3 days. Pile covered August 15th.

Exp. No. $11(6)$. Kerosene emulsion treatment. Manure piled August 12th. On August 15th third stage larva found in upper layers. Pile sprayed same day, August 15th, with kerosene emulsion 1 in 9 strength; $4 \frac{1}{2}$ gallons used for the whole pile. This pile contained a little more straw than other piles. Pile covered August 15th. 


\section{Emergence of Fuies}

The following table summarizes the results of these experiments which have been arranged in order according to the number of flies emerging from the various piles.

EXPERIMENTS WITH LARVICIDES

\begin{tabular}{|c|c|c|c|c|}
\hline \multirow{2}{*}{ Treatment } & \multicolumn{2}{|c|}{ Number of Flies Emerged } & \multirow{2}{*}{ Total } & \multirow{2}{*}{ Experiment Number } \\
\hline & Top Cages & Bottom & & \\
\hline Control. Untreated. & 8,729 & 4,603 & 13,332 & 11 (1) \\
\hline Zenoleum ......... & 229 & 7,811 & 8,040 & $11(4)$ \\
\hline Iron Sulphate .......... & 5,546 & 2,304 & 7,850 & $11(2)$ \\
\hline Chloride of Lime (surface) & 857 & 5,086 & 5,943 & $11(3)$ \\
\hline Chloride of Limc (mixed). & 901 & 3,726 & 4,627 & $11(5)$ \\
\hline \multirow[t]{2}{*}{ Kerosene Emulsion....... } & 832 & 2,649 & 3,481 & $11(6)$ \\
\hline & 17,094 & 26,179 & 43,273 & \\
\hline
\end{tabular}

From the foregoing experiments kerosene emulsion appeared to be the most effective insecticide. I am inclined to believe, however, that the greater proportion of straw in this experiment, No. $11(6)$, affected the results, and I should be inclined to prefer the chloride of lime treatment pending further results, especially as kerosene emulsion is considered, I believe, by chemists to affect the manurial values of the stable refuse.

These preliminary results, however, are not given for the purpose of drawing conclusions as to the best insecticide, but rather to indicate a method whereby such results may be obtained.

\section{Pupation}

Among the miscellaneous observations made during the past season's work, the following may be mentioned: It was found that the mature larvæ generally left the manure heap to pupate and buried themselves in the sand some distance away from the heap. That the majority of the larvæ travelled some distance before pupating is demonstrated in the following table in which it is seen that in the aggregate a greater number of flies were captured in the bottom cages, that is, the cages attached to the cheese cloth outside the wooden covers, in which cages the flies emerging from pupæ outside the wooden covers were captured.

In the cages on the top of the wooden covers, referred to as the top cages, the flies emerging from pupæ within the sides of the wooden covers were captured and these were less in number than the flies emerging from pupæ outside the wooden covers.

Larvæ were found pupating at a distance of two feet from the manure pile and at a depth of nine inches. 


\section{Temperatures of. Manurie and Their Significance}

In the course of these experiments some significant observations were made on the temperature of the manure piles. The heating of the freshly piled manure is a matter of common knowledge and observation, but I have not seen any reference to its relation to the breeding of house-flies beyond the general statement that the higher temperature accelerated the development which my own experiments carried out some years ago under controlled incubator conditions demonstrated. Newstead found that at $100^{\circ} \mathrm{F}$. the larvæ were uncomfortable and left the manure. In incubator experiments I found that a temperature of $104^{\circ} \mathrm{F}$. was too great for the larvæ and anything above that roasted them alive.

If we examine the temperature of a pile of manure taken at a time when it is fresh, attractive to flies and inhabited by larvæ, the results are somewhat surprising and significant. The following are the temperatures which were taken in connection with two of the experiments:

\begin{tabular}{|c|c|c|c|}
\hline Expmt. No ................ & $11(1)$. & $11(4)$. & $11(5)$. \\
\hline 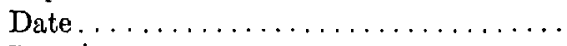 & August 8. & August 9 . & August 15. \\
\hline Length of time manure exposed . & 3 days. & 2 days. & 2 days. \\
\hline Atmospheric conditions........ & $\begin{array}{l}\text { Sunny, cool } \\
\text { wind. }\end{array}$ & $\begin{array}{l}\text { Oppressive, } \\
\text { alternately } \\
\text { sunny. }\end{array}$ & $\begin{array}{l}\text { Oppressive, } \\
\text { sunny alter- } \\
\text { nately. }\end{array}$ \\
\hline Air temperature. & $86^{\circ} \mathrm{F}$. & $78^{\circ} \mathrm{F}$ & $103^{\circ} \mathrm{F}$ \\
\hline on surface of $n$ & $97^{\circ} \mathrm{F}$. & $87^{\circ} \mathrm{F}$. & - \\
\hline Temp. 1 in below surface... & - & $106^{\circ} \mathrm{F}$. & - \\
\hline Temp. 4 in. below surface. . . . . . . . . & $156^{\circ} \mathrm{F}$. & $145^{\circ} \mathrm{F}$. & 一 \\
\hline Temp. 6 in. below surface. . & $158^{\circ} \mathrm{F}$. & 一 & - \\
\hline Temp. 10 in. below surface. ......... & $164^{\circ} \mathrm{F}$. & - & $160^{\circ} \mathrm{F}$. \\
\hline
\end{tabular}

From the above temperature records it will be seen that at no great depth from the surface of the manure piles the heat was too great to permit the existence of the larvæ, and this fact was supported by observation. On the top of the pile the larvæ were only living in the surface layer, that is, the habitat was peripheral and the excessive internal heat due to fermentation becomes practically a larvicide.

It is evident that in a well-packed manure heap, I am not speaking of small or loosely piled heaps, that only the peripheral region is infested by the house-fly larvæ, and that they do not, as a rule, penetrate deep into the central regions. In loosely piled heaps it would be possible for them to penetrate more deeply. The cooling of the whole heap might conceivably permit the deeper penetration of subsequent broods, but against this should be set the fact that the outside region 
of the heap has by this time become less attractive to the flies owing to exposure and the fact that larvæ have already worked over it.

Reference was made earlier in the paper, in discussing the relative merits of counts of larvæ or of flies emerging as standards of comparison in judging insecticide values, to the difficulty of obtaining a fair sample of a manure heap. This fact is emphasized by the foregoing observations. Further, calculations have been made of the number of flies which might be produced from larvæ in a manure pile of a given size based upon estimates of the number of larvæ occurring in a pound of manure. Such estimates are obviously far from accurate, and while it may be a good policy to impress the lay mind with potential dangers of a heap of stable refuse, we should not do so at the expense of veracity. I $\mathrm{am}$ ashamed to admit that our knowledge of the breeding habits of the house-fly in manure piled under various conditions is by no means as complete as it should be and it is very deșirable that other workers should make observations on such habits as the conclusions may prove of no little value in aiding the agriculturalist in the problem of the control of breeding places. If the conclusions in regard to the peripheral breeding habits of the fly in well-piled manure are correct, the advantage of storing in concrete and wooden chambers receives material support.

Mr. L. O. Howard: Experiments have been carried on in Washington and New Orleans of a similar character to those given by Doctor Hewitt and I would like to ask Mr. W. D. Hunter if he will explain what has been done in this direction.

Mr. W. D. Hunter: This year Doctor Howard inaugurated a series of house-fly experiments in Washington, almost parallel with Doctor Hewitt's. They grew out of the idea that Doctor Howard had had for several years that the whole subject of the treatment of the breeding places of the house-fly had not been sufficiently investigated. The same idea Doctor Hewitt has mentioned occurred to Doctor Howard, that is, the necessity for basing experiments upon consideration of the effect of applications on the manure. At that juncture Doctor Howard called upon the Bureau of Chemistry, and coöperative experiments were begun, the Bureau of Entomology looking after the entomological part of the work, and the Bureau of Chemistry to determine the effect of the different applications upon the chemical composition of the manure, and a bacteriologist was brought in at the same time to determine the activity of the bacteria of the manure. Without knowing, as far as I am aware, of the plans that Doctor Hewitt 
was putting into operation in Canada, we devised a series of cages very similar to his. There was a double wall provided to prevent infestation by eggs that might be deposited on the outside by flies, that would be attracted by the odor of the manure. The cages were supported on four legs about 6 inches high. Part of the apparatus was a galvanized iron pan, in which the seepage from the deposit could be collected for chemical examination.

Doctor Hewitt referred to the fact that in most of the experiments of this kind that have been performed only one of the two important series of observations had been made. In some cases the manure has been examined to determine the effect on the fly larvæ. In such cases the determination of the number of flies emerging was overlooked, and in the other case the number of flies emerging would be determined, and the effect on the larva would be overlooked. Consequently, in our series of experiments we took both of these factors into consideration. On one side of these cages a small opening was provided. Through that opening, from time to time, after the manure was placed in the cage, small samples were extracted. A portion of the samples was used by the chemist to determine the effect of the application, and at the same time the exact mortality of house-flies was determined. These observations were made in more or less extensive series, so that the results could be averaged, and at least an approximately true index of the situation obtained. The number of adult flies emerging was watched in practically the same fashion as Doctor Hewitt's experiments. Wire fly-traps were placed on top, and the exact number was determined. We, therefore, had two methods of checking up the results; first, the actual examination of the larvæ in the manure to determine the mortality, and, second, the actual emergence of adults. We had the same difficulty that Doctor Hewitt encountered in obtaining a uniform infestation. We found no very satisfactory method of obivating that. We did what we could towards obviating it by mixing the material very well, exposing it first, then having it shovelled up, so as to approximate uniformity of infestation. I should say in this connection also that liberal allowance was made for control cages, that is, every time one of these series of experiments were started, three or more cages were used, in which the manure was not treated. In those cages the same examinations were made as to deaths and flies emerging. In that way, allowance was made for the normal mortality in the manure.

We had planned to use all of the substances that had been recommended for fly control, and any others, that might be suggested by the chemist. We used salt, borax, copper sulphate, iron sulphate, a number of proprietary substances, creosote, etc. The series of experi- 
ments were so interesting; and the results so definite that, as the fly season was drawing to a close, Doctor Howard and Doctor Alsberg arranged to transfer the whole work to the ('ity of New Orleans, where the flies would be active for perhaps two months longer. Certain series of experiments were repeated in the hope that results would become so definite that something could be published and used throughout the country at the beginning of the next fly season. Doctor Cook, of the Bureau of Chemistry, and Mr. Hutchinson, my associate, have just completed that second series of experiments in New Orleans. Mr. Hutchinson is here today. In a very short time we expect to place the results on record.

In connection with this investigation we undertook to work out some of the points in the life history of the fly, on which our information has been very meagre, as has been pointed out by Doctor Hewitt in his noteworthy work on the house-fly and Doctor Howard in his recent book. One of these points particularly was the duration of the period between the emergence of the adult flies and their attaining sexual maturity, that is, the pre-oviposition period. I think all the members of the Association are familiar with the basis of the socalled Hodge plan of controlling flies. In bricf, Doctor Hodge's plan is to ignore, at least in a large part, the breeding of flies in stable manure, and devote the attack against the adults. That is the result of some experiments performed some years ago by Doctor Hewitt. He found the pre-oviposition period ran as bigh as ten to fifteen days. During that time there was no danger of depositing eggs, but the adult flies are going about getting food.

We were very much interested in getting complete data. Mr. Hutchinson would take a number of flies, place them in a jar with some food material that would be suitable, and would leave them in a certain c'age for 24 hours. Then they would be taken out and the cage recovered, and observations made later as to whether any eggs had been deposited or any larvæ could be found. In a second cage the flies remained there 48 hours, and so on up to an indefinite number of 24-hour periods. In this way we hoped by the repetition of the experiments to obtain absolutely accurate information on this point. The results have not been assembled completely at this time, but the indications are very plainly that this pre-oviposition period is much shorter than the preliminary experiments of Doctor Hewitt had indicated. That emphasizes the importance of the point brought out by Doctor Headlee - the absolute importance of directing efforts against the place where they might be breeding.

Just one other point. Doctor Headlee and Doctor Hewitt have both referred to the limited distribution of the fly larvæ in the piles of 
manure. In connection with this series of experiments at the Arlington farm, Mr. Hutchinson was astonished one day to find that a large number of his larvæ were escaping. He began to investigate the matter. By examining many piles of manure near Washington he found a concentration of larvæ and pupæ in the peripheral ring near the outer surface. Immediately he considered the factors of moisture and temperature, that might be instrumental in bringing about this condition. The result of the observations of Mr. Hutchinson led him to the belief that moisture is more important than temperature. In fact, he has performed a series of experiments, in which he has regulated practically the location of the pupæ by the administration of water. This led to one point, that may be of great importance. He has found that, where the manure piles are completely saturated with water, the larvæ will make their way outside. The instinct of the larvæ is to obtain a location where there is an optimum of conditions and where the adults can make their exit. A practical application in a stable would be to throw the manure upon a frame work and keep it saturated with water. By that system the experiments show the larvæ will all fall through the bottom to the floor. In the case of a cement floor, it would be possible to flush them into the drain, or dispose of them some other way. On a farm the manure might be placed on a platform and the larvæ forced by the application of water to make their way out to be eaten by the chickens.

I would like to congratulate Doctor Hewitt on this very important work that he has done. I think that all the members of the Association think that the high standard, that he set, when he wrote the book on the house-fly, has been maintained by the series of practical experiments, which he has described this morning.

Mr. C. Gondon Hewitr: A number of years ago when I carried on house-fly work, I was able to devote all my time to it. Now it is possible for me to carry it on only during spare time. I would urge Doctor Howard and his associates to continue to carry on these experiments as they are very imporiant. With regard to the pre-oviposition period, the single series of experiments which I carried on in Manchester, England, gave but few results and were not intended to do more than to give general information. The mean temperature in Manchester, England, is much less than in this country, consequently the pre-oviposition period there would be longer.

In the experiments which I mentioned in my paper I found that flies were emerging on the outside of the wooden cages before the cheesecloth bottom was attached. During the hot days the newly emerged. flies crawled up on the outside of the cages and the males copulated with the females immediately. This shows that the female fly may 
become fertilized very soon after emergence. In regard to the suggestion made by $\mathrm{Mr}$. Hunter as to watering manure in stables, it would appear to me that this would have the disadvantage of decrcasing the manurial value. We must be very careful about advising farmers to adopt a suggestion of this kind, for such a process would result in the loss by leaching of the soluble plant food in the manure.

Mr. Z. P. Metcalf: The town of Asheville, N. C., was one of the first to take up active work against the house-fly and is one of the few towns in the South that is continuing the work. The Board of Health required that manure be placed in tight receptacles and damped very slightly. While Asheville is not a flyless town, it is very much better in this respect than most towns of its size in the South.

President P. J. Parrott: We will now listen to a paper by Prof. S. J. Hunter, entitled

\section{THE SANDFLY AND PELLAGRA, III ${ }^{1}$}

By S. J. Hunter, Universily of Kansas, Laurence

\section{Summary of Progress}

The work of obtaining evidence which would either confirm or refute the Sambon theory was continued this year under a special fund furnished by the Board of Educational Administration. The responsibility for the entomological side of the question rests with the author and the pathological side as manifested by the monkeys subjected to the bite of the sandfly rests with Dean Crumbine of the Medical School.

In this connection it may properly be noted here that since the publication of the last paper Harris has published an account of his results in producing pellagra experimentally in monkeys. Based upon his experiments, then, the monkey becomes a susceptible animal.

The two most important additions to our studies are fixed on the biting habits and morphology of the mouth parts of Simulium vitattum.

Heretofore, we experienced little difficulty in encouraging the sandfly to bite the patient but no extended attention had been given to the biting habits in nature.

Last August, owing to the limited water supply in the principle sandfly inhabited brooks, this part of the study was transferred to Madison River in southern Montana where all stages of the fly were unusually abundant. Here it was observed that the fly would bite the exposed parts and was more active on cool days while the temperature was below $70^{\circ} \mathrm{F}$.

'For papers I and II see this journal, Vol. V, No. 1, Feb., 1912, pp. 61-63, and Vol. VI, No. 1, Feb., 1913, pp. 96-101. 